Revista de Economia Política, vol. 29, nº 2 (114), pp. 163-190, abril-junho/2009

\title{
Os dois métodos e o núcleo duro da teoria econômica
}

\section{LUIZ CARLOS BRESSER-PEREIRA*}

The two methods and the hard core of economics. While methodological sciences have no object and are supposed to adopt a hypothetical-deductive method, substantive sciences including economics should use an empirical or historicaldeductive method. The great classical economists and Keynes did that and were able to develop open models explaining how equally open economic systems work. Thus, the hard core of relevant economics is formed by the classical microeconomics and the classical theory of capitalist economic growth, and by Keynesian macroeconomics. In contrast, neoclassical economist aiming to build a mathematical science wrongly adopted the hypothetical-deductive method, and came to macroeconomic and growth models that do not have practical use in policymaking. The exception is Marshall's microeconomics that does not provide a model of real economic systems, but is useful to the analysis of markets.

Keywords: hypothetical-deductive method; historical-deductive method; open systems; mathematical economics; new historical facts.

JEL Classification: B10; B20; B41.

O problema teórico central enfrentado pela economia e pelas outras ciências sociais é a escolha do método ou abordagem preferidos de investigação. Economistas clássicos como Smith, Malthus e Marx usaram essencialmente o método histó-

\footnotetext{
* Professor Emérito da Fundação Getulio Vargas. E-mail: lcbresser@uol.com.br Este trabalho baseia-se no curso de Metodologia Científica para Economistas que venho ministrando desde 1989. Meus especiais agradecimentos vão para Ramón Garcia Fernandez e José Marcio Rego, que dividem comigo a responsabilidade por ele. Agradeço também os comentários de Adam Przeworski, Alexandra Strommer de Godoy, Alain Herscovici, Eleutério Prado, Gilberto Tadeu Lima, Leda Paulani, Marcos Ribeiro Ferrari, Paulo Gala, Robert Nicol, Solange Marin, Victoria Chick e Yoshiaki Nakano. Uma primeira versão deste trabalho foi apresentada na Reunião Anual da Associação Europeia de Economia Política Evolucionária, em Maastricht, em novembro de 2003. A versão em ingles deste trabalho está sendo publicado conjuntamente pelo Journal of Post Keynesian Economics.
} 
rico-dedutivo: tentaram generalizar a partir da observação da realidade econômica que os cercava. Ricardo desenvolveu modelos altamente dedutivos, mas os fatos básicos em que baseou seu raciocínio, como as maiores rendas recebidas pelos proprietários das terras mais produtivas, vieram de sua observação da realidade econômica. A ideia de adotar o método hipotético-dedutivo ocorreu a Stuart Mill (1836), que sugeriu que com ele - isto é, com a adoção do homo economicus como pressuposto básico - a economia seria capaz de superar seu caráter impreciso. Ele mesmo não fez pleno uso do método, mas a partir dos anos 1870, com o surgimento da escola neoclássica, esse método começou a ser ativamente adotado. No entanto, como Marshall era a figura dominante da escola neoclássica e um grande economista, a formalização da economia e sua alienação da realidade não ocorreram imediatamente. A redução da teoria econômica a modelos matemáticos possibilitada pela abordagem hipotético-dedutiva aconteceria nos anos 1930, quando um grande número de engenheiros e físicos se juntaram à profissão (Mirowski, 1991). Keynes representou uma reação à primazia do método hipotético-dedutivo na teoria econômica e a sua consequência, a tendência à "matematização" do pensamento econômico. Utilizando essencialmente um método histórico-dedutivo, ele mudou a história do pensamento econômico e da formulação de políticas econômicas. Em breve, porém, depois que Arrow e Debreu formalizaram plenamente o modelo do equilíbrio geral, a teoria econômica neoclássica voltou à abordagem hipotético-dedutiva (Blaug, 2002), enquanto o modelo de Solow tornava a teoria econômica do crescimento compatível com o equilíbrio geral. Um pouco mais tarde, a aceitação das expectativas racionais pela teoria macroeconômica neoclássica também permitiu sua compatibilização com o equilíbrio geral.

Seguiu-se um breve período de encantamento com a consistência lógica alcançada, mas logo as realidades econômicas efetivas se impuseram. O primeiro sinal da crise com que vem se defrontando a teoria econômica neoclássica surgiu quando os bancos centrais abandonaram a política de metas monetárias. Atualmente, está claro que a teoria macroeconômica neoclássica e a teoria neoclássica do crescimento que usam o método hipotético-dedutivo são incapazes de explicar e prever o comportamento das complexas realidades sociais e institucionais. O pensamento econômico acadêmico dominante entrou em crise, e muitos são os sinais. Como afirmou Mark Blaug (2002: 36), "a teoria econômica moderna está doente; ela se tornou cada vez mais um jogo intelectual jogado por si mesmo e não por suas consequências; os economistas gradualmente converteram o objeto em uma Matemática Social, onde o rigor analítico, como entendido na matemática, é tudo, e a relevância empírica (como entendida nos departamentos de física) é nada”. Enquanto no nível de graduação os manuais continuam basicamente a ensinar a boa teoria macroeconômica keynesiana, a maior parte da teoria macroeconômica das expectativas racionais ensinada no nível pós-graduação tem pouca utilidade prática. Como reconheceu um eminente macroeconomista neoclássico, Gregory Mankiw (2006: 42), resumindo sua própria experiência em Washington, a macro- 
economia "científica" definitivamente não é usada pelos formuladores de políticas; o que eles usam é essencialmente a macroeconomia keynesiana. Em suas palavras: "A triste verdade é que a pesquisa macroeconômica das últimas três décadas teve apenas um impacto limitado sobre a análise prática da política monetária”. ${ }^{1}$ Teve, no entanto, importância prática no processo de desregulação dos sistemas financeiros que levou à grande crise do sistema bancário de 2007-2008.

Neste trabalho, discuto a metodologia econômica que opõe esses dois métodos, critico, com base nisso, a teoria econômica neoclássica na medida em que ela pretende analisar sistemas econômicos usando o método hipotético-dedutivo, e concluo que o núcleo da moderna teoria econômica não é formado pelo modelo do equilíbrio geral, pelo modelo de Solow e pelo modelo macroeconômico neoclássico, mas pelas teorias que foram desenvolvidas com base no método histórico-dedutivo: pela teoria clássica da alocação de recursos, da distribuição e do crescimento, e pela macroeconomia keynesiana. Enquanto esses são modelos abertos que conseguem analisar o sistema econômico, na medida em que apresentam uma razoável correspondência com a realidade e oferecem políticas práticas, os modelos fechados falham nessa tarefa, na medida em que adotam o método hipotético-dedutivo que é apropriado às ciências metodológicas; nas ciências substantivas, como a economia, esse método desempenha ou deveria desempenhar somente um papel subsidiário. Na seção I, introduzo a discussão dos dois métodos e argumento que, enquanto o método hipotético-dedutivo é apropriado às ciências metodológicas, o método empírico-dedutivo é apropriado às ciências substantivas. Na segunda seção, alego que, como o objetivo da economia é a análise e a previsão do comportamento dos sistemas econômicos, o método histórico-dedutivo deveria ser o principal método adotado. Nas terceira e quarta seções, discuto a aplicação efetiva dos dois métodos pelas escolas econômicas. Na quinta seção, retomo minha crítica principal à escola neoclássica com base não tanto no fato de seu pressuposto principal ser o homo economicus, mas por tentar deduzir dele o núcleo da teoria econômica. Na sexta seção, concluo que o núcleo da teoria econômica relevante é formado principalmente pelas contribuições das escolas clássica e keynesiana; seus modelos são menos elegantes e completos, mas têm maior capacidade de explicar os sistemas econômicos. No entanto, saliento que a microeconomia marshalliana, desconsiderados seus objetivos comportamentais de caráter substantivo, tornou-se uma ferramenta metodológica que

\footnotetext{
${ }^{1}$ Nesse trabalho, Gregory Mankiw vê a teoria macroeconômica neoclássica baseada na escolha racional como "científica", enquanto a teoria econômica keynesiana seria uma espécie de "engenharia". Ele observa a continuada aplicação da macroeconomia keynesiana, e lamenta a falta de aplicação prática da macroeconomia neoclássica; ele alega que seu próprio grupo, a Escola Neokeynesiana (na verdade uma escola neoclássica) é um pouco mais prático, mas não muito; e espera que, no futuro, o fosso entre as realizações dos "engenheiros" e as não-realizações dos "cientistas" diminua. Alain Blinder (1998), que também teve experiência em Washington, chegou a conclusões similares, oito anos antes, sobre a irrelevância da teoria macroeconômica acadêmica para os responsáveis pelos bancos centrais.
} 
é hoje essencial para analisar os mercados e para se tomarem decisões - e pode ser assim considerada uma ciência metodológica auxiliar da teoria econômica.

\section{OS MÉTODOS HIPOTÉTICO-DEDUTIVO E HISTÓRICO-DEDUTIVO}

Em todas as ciências, pressupõe-se sempre combinar indução e dedução. Mas uma das duas abordagens tende a ser dominante. Muitos acham que, na economia, o único método totalmente científico é o hipotético-dedutivo porque ele, sozinho, permite hipóteses precisas e quantificáveis. Na medida em que o método parte de um princípio - o homo economicus, cujo comportamento é totalmente previsível - complementado com alguns outros pressupostos, esse método possibilita uma teoria precisa e matemática. Ao contrário, o método histórico-dedutivo não parte de simples pressupostos, mas da observação de uma realidade complexa e em mudança. Ambos são dedutivos, mas enquanto um é hipotético - partindo de um pressuposto - o outro é histórico - partindo de sequências observadas de fatos e mantendo-se próximo a eles durante o processo dedutivo.

Neste trabalho, começo com um pressuposto diferente. Partindo de uma classificação básica das ciências, distingo as "ciências metodológicas", como a matemática, a estatística, a econometria e a teoria dos jogos, que não têm um objeto de estudo mas são instrumentais para o raciocínio, das "ciências substantivas", que têm um objeto (Hempel, 1966). Estas últimas se subdividem em ciências naturais, como a física e a biologia, e ciências sociais, como a economia e a sociologia. Presume-se que as ciências metodológicas adotem o método hipotético-dedutivo, e suas proposições e modelos têm a consistência lógica como critério de verdade, enquanto as ciências substantivas deveriam usar basicamente o método históricodedutivo, e suas proposições e modelos têm como critério de verdade a coerência com a realidade ou, em termos pragmáticos, a capacidade de previsão - sua capacidade de orientar a ação. ${ }^{2}$ Dado que a economia é uma ciência social substantiva, cujo objeto é aberto e complexo - os sistemas econômicos -, argumento que a economia deve usar principalmente o método histórico-dedutivo. Ela só deve recorrer secundariamente ao método hipotético-dedutivo, aqui entendido como o processo de raciocínio que parte do pressuposto da racionalidade econômica e deriva a teoria desse pressuposto básico. O uso do método hipotético-dedutivo é legítimo, porque se presume que todas as ciências desenvolvam seus próprios conceitos e modelos heurísticos. Além disso, se entendermos que o objetivo da economia é explicar os sistemas econômicos e desenvolver ferramentas para entender os mer-

\footnotetext{
${ }^{2}$ Charles Peirce, fundador do pragmatismo, desenvolveu esse critério pragmático. Ele costuma ser visto como um relativista. Na verdade, é um realista pragmático. Não pode ser considerado um relativista, a menos que tenhamos uma compreensão mais ampla de relativismo. Ver Wiener (1958) e Hoover (1994).
} 
cados, ela terá de usar o método hipotético-dedutivo para desempenhar esse segundo papel. Mas o método histórico-dedutivo deve ter precedência, porque a complexidade e o caráter de mudança dos sistemas econômicos tornam impossível derivar modelos relevantes apenas de algumas hipóteses. ${ }^{3}$

Em nossa sociedade há uma espécie de reverência para com a matemática que faz com que cientistas que lidam com objetos substantivos espelhem a matemática e desenvolvam modelos fechados que são logicamente consistentes, mas que não têm quase nenhuma relação com o objeto que deveriam analisar - no caso da economia, o sistema econômico. Descartes observou que a matemática é a única disciplina dotada de evidência e certeza, e sugeriu que tais critérios deveriam ser aplicados a todas as ciências. Kant era da mesma opinião. Embora reconhecendo que a matemática não tem outro objeto além da construção racional, ele a encarava como ciência per se, na qual se realiza amplamente o raciocínio a priori por meio de demonstrações dedutivas precisas. Mas ele reconhecia que a física - a ciência substantiva que utilizou com maior sucesso o método hipotético-dedutivo e se aproximou da abordagem matemática - não poderia ter a precisão da matemática. Descartes e Kant estabeleceram um ideal matemático para as ciências substantivas - naturais e sociais - ignorando ou subestimando o fato de que, ao contrário da matemática e da lógica, as ciências substantivas têm um objeto ou substância que é complexo e que pode ser efetivamente analisado somente se for investigado empiricamente, se a indução e a dedução forem sistematicamente combinadas. Modernamente, Carl Hempel - que se via como representante não do positivismo lógico que define o Círculo de Viena mas do empirismo lógico - defendia explicitamente que o método hipotético-dedutivo deveria ser aplicado a ciências com mais do que mero conteúdo formal. Isso seria verdade se ampliássemos nosso conceito do método hipotético-dedutivo e considerássemos que todos os modelos que partem de uma observação ou de um evento real seriam também hipotético-dedutivos. $\mathrm{Na}$ verdade, neste caso, o método básico utilizado é o método histórico-dedutivo: a observação vem em primeiro lugar. $\mathrm{O}$ problema não está em rejeitar o uso do método hipotético-dedutivo nas ciências substantivas, mas em atribuir-lhe prioridade em relação ao método empírico-dedutivo. Isso é um erro, tanto quanto usar como critério de verdade principal a consistência lógica em lugar da adequação à realidade e/ou previsibilidade.

O problema dos dois métodos não é exclusivo da teoria econômica. Existe também na filosofia e na ciência política. Enquanto os filósofos que utilizam basicamente o método hipotético-dedutivo tendem a ser idealistas, reconhecendo a realidade apenas representada em ideias, os filósofos que adotam basicamente o método histórico-dedutivo são realistas. Em teoria política ou filosofia política, seguindo a tra-

\footnotetext{
${ }^{3}$ Como o método hipotético-dedutivo e o método empírico ou histórico-dedutivo comungam da palavra "dedutivo", essa palavra poderia ser omitida. Mas eu a conservo para enfatizar a importância da dedução em qualquer processo de conhecimento e também, no caso do método histórico-dedutivo, para evitar confundi-lo com a mera análise histórica, que não pretenderia deduzir uma teoria.
} 
dição histórica fundada por Aristóteles, o Estado ou o regime político eram vistos como resultado de uma evolução histórica, como produto de um processo de crescente divisão do trabalho e de formas históricas de dominação: tribos, clãs, cidades, cidades-Estado, impérios. Com Hobbes, entretanto, e a teoria contratual, o Estado é logicamente deduzido a partir da hipótese da existência prévia de um estado de natureza, onde a guerra entre os homens era a única realidade, e da decisão dos homens, em certo momento, de estabelecerem um contrato através do qual renunciavam à sua liberdade original em favor de uma ordem legal imposta pelo Estado. As hipóteses não tinham correspondência na realidade mas, adotando essa estratégia teórica, os filósofos contratualistas foram capazes de deduzir logicamente o Estado a partir da vontade dos indivíduos livres. A legitimidade do monarca deixou de ser ancorada na tradição e na religião para se originar do contrato social. Mesmo se Hobbes, com sua teoria, pretendia fortalecer o poder do monarca absoluto alterando a base da legitimidade do poder político, ele e seus grandes sucessores iluministas apenas abriram caminho para os modernos conceitos de povo e cidadania e para a realidade dos regimes democráticos. O contratualismo, embora irrealista, estabeleceu poderosas bases normativas para o desenvolvimento político futuro dos Estadosnação, e foi uma ferramenta para a afirmação dos direitos civis e políticos. Deve-se ressaltar, porém, que o método hipotético-dedutivo permitia apenas um conceito muito abstrato e normativo de Estado. Para a análise efetiva dos regimes políticos ou para a compreensão das várias formas que o Estado moderno assumiu histórica e geograficamente, a precedência do método histórico-dedutivo é pertinente.

Com os grandes economistas mercantilistas e clássicos, a teoria econômica ou economia política começou como uma ciência social histórico-dedutiva. Já na década de 1830, Stuart Mill, objetivando dar à teoria econômica uma precisão semelhante à da matemática, propôs a adoção do homo economicus. Ele sabia que esse objetivo era impossível, mas em seu ensaio metodológico de 1836 sugeriu que é possível se aproximar dele com o auxílio desse pressuposto e do método hipotéticodedutivo correspondente. ${ }^{4}$ Nos anos 1870 , a história do pensamento econômico sofreu uma grande mudança. O desenvolvimento de uma alternativa à teoria do valor-trabalho (que tinha se mostrado pouco amigável depois da teoria da maisvalia de Marx) - a teoria do valor subjetivo ou da utilidade marginal - criou espaço para a predominância da escola neoclássica ou marginalista. A teoria econômi$\mathrm{ca}$, coroada pelo modelo do equilíbrio geral, logo se tornou a mais radicalmente bipotético-dedutiva de todas as ciências substantivas. ${ }^{5}$ Esse predomínio foi contestado pela revolução keynesiana, que chegou em um momento de crise de um siste-

\footnotetext{
${ }^{4}$ Stuart Mill (1836). Sobre a metodologia econômica de Mill, ver Hausman (1992).

${ }^{5}$ Essa culpa, no entanto, não pode ser atribuída a Walras, que estava efetivamente preocupado com o mundo real. O equilíbrio racional viria de um difícil processo que ele denominou tâtonnement [tentativa e erro]. Como ressalta Blaug (2002: 37), foi depois do modelo Arrow-Debreu que a economia se tornou "puramente formal" - puramente hipotético-dedutiva.
} 
ma econômico que pretendia ser e dever ser puramente coordenado pelo mercado. Além de legitimar um sistema econômico misto, coordenado pelo mercado e pelo Estado, pela primeira vez Keynes e Kalecki ofereceram um modelo macroeconômico completo das modernas economias capitalistas. A partir da década de 1970, entretanto, o pensamento econômico dominante foi novamente atraído pela consistência e precisão possibilitadas pelo uso do método hipotético-dedutivo - e o raciocínio neoclássico foi restaurado na teoria econômica acadêmica. Depois disso, o problema que o pensamento econômico dominante enfrentará é, mais uma vez, a falta de capacidade explicativa e de previsão. Além de se tornar um conjunto de modelos abstratos, ele se torna também cada vez mais normativo em lugar de positivo, na medida em que o método hipotético-dedutivo na ciência social leva a esse resultado. Se deduzimos algo a partir do pressuposto do agente econômico racional, isso significa não apenas que o agente econômico geralmente age assim, mas também que ele "deveria” agir assim.

Nas outras ciências sociais, particularmente na sociologia e na antropologia, o método histórico-dedutivo continuou dominante depois de Marx, Durkheim e Weber, mas sob ataque. Weber, com sua teoria da ação, abriu caminho para uma forma moderada de individualismo metodológico baseado em uma busca a posteriori de explicações racionais, mas continuou sendo um analista essencialmente histórico (Weber, 1922: cap. 1). O mesmo aconteceu com a escola sociológica da modernização que tem em Talcott Parsons seu principal representante. Na segunda metade do século XX, porém, juntamente com a restauração neoclássica, a teoria da escolha racional apareceu na ciência política, tendo como inspiração a microeconomia neoclássica. Como no caso das teorias filosóficas contratualistas, ela possibilitou vários desenvolvimentos interessantes na discussão das instituições políticas. No entanto, ela presume radicalmente que os agentes políticos se comportam como os agentes econômicos, tentando maximizar sua utilidade pessoal, e estabelece uma estreita analogia entre mercado e política. ${ }^{6}$ Isso não faz sentido na esfera política, onde o interesse próprio não é o critério único das ações, onde os servidores públicos eleitos e não eleitos devem também se guiar pelo interesse público. Quando os pesquisadores da escolha racional estão preocupados apenas em encontrar explicações racionais a posteriori para fenômenos sociais e políticos que são analisados historicamente, essa abordagem pode ser proveitosa, particularmente ao atribuir precisão e coerência interna ao raciocínio; depois de usar o método histórico-dedutivo para apreender o sistema econômico ou político, o cientista político pode complementar seus achados com a busca das causas racionais subjacentes. ${ }^{7}$ Mas, ao fazer isso, os cientistas políticos (mais do que os economistas)

\footnotetext{
${ }^{6}$ Anthony Downs (1957) inaugurou esse caminho equivocado.

${ }^{7}$ A análise clássica da democracia social de Przeworski (1985) é um bom exemplo dessa abordagem a posteriori.
} 
devem levar em conta, como sugerido por Jon Elster (1997), que seu conceito de racionalidade deve ser mais amplo, incluindo questões de interesse público, pois as leis que governam o mercado não são as mesmas que regem o fórum. E devem levar em consideração também as limitações sociais ou históricas impostas aos agentes pelas características estruturais, culturais e institucionais da sociedade, que são eminentemente históricas.

O método histórico-dedutivo pode também ser chamado de empírico-dedutivo, que é a denominação mais apropriada quando nos referimos às ciências naturais. Enquanto o método empírico-dedutivo é principalmente analítico, o método histórico é ao mesmo tempo analítico e dialético. O método analítico se aplica às ciências naturais e metodológicas, particularmente à física. ${ }^{8}$ No caso das ciências sociais, é praticamente inevitável pensar não apenas historicamente mas também em termos dialéticos. $\mathrm{Na}$ esfera social, causas e consequências não se distinguem claramente, e a consequência quase sempre retroalimenta a causa presumida. A realidade social é intrinsecamente histórica, porque está em permanente mudança, e é intrinsecamente contraditória, porque os sistemas sociais se compõem de atores individuais que, embora socialmente condicionados ou determinados, são livres e responsáveis para fazer escolhas que muitas vezes são conflitantes; porque são atores em processo de aprendizado, que mudam com a experiência; e porque, ao fazer isso, eles mudam permanentemente as estruturas sociais e principalmente criam cultura e instituições que, por sua vez, mudam as preferências individuais.

Nas ciências sociais, onde a observação empírica é crucial, mas a justificação é sempre relativa, a lógica da descoberta desempenha um papel importante. É por isso que a hermenêutica se tornou tão relevante em nossa época. Não vou tão longe como alguns pensadores hermenêuticos e pós-modernos que derivam da complexidade e ambiguidade dos sistemas sociais e econômicos uma negação relativista da possibilidade de chegar à verdade, mas sou igualmente crítico da arrogância intelectual presente na tentativa de cientistas sociais - particularmente economistas - de reduzir essa complexidade e ambiguidade a modelos desprovidos de conteúdo de realidade. Embora os economistas admitam facilmente a necessidade de um método positivo ou empírico para estudar seus respectivos objetos - e por essa razão vejo a econometria como uma poderosa ferramenta para atingir esse objetivo - eles aspiram paradoxalmente a um modelo de realidade absolutamente preciso. Se esse ideal não pode ser alcançado nas ciências naturais, nem mesmo na física, onde os elementos que formam os sistemas em estudo não têm liberdade de escolha, o que dizer das ciências sociais, onde os seres humanos não apenas têm essa liberdade, mas podem aprender com a história, construir instituições e modificar seu comportamento de acordo com isso?

Reconheço que as afirmações que faço neste trabalho são ousadas - que, se

\footnotetext{
${ }^{8}$ É menos aplicável à biologia, onde as relações causais costumam ser substituídas pelas relações funcionais.
} 
forem verdadeiras, permitem uma compreensão diferente da economia e das escolas econômicas. Mas elas não vêm do nada. Há uma antiga tradição de economistas que usam explicitamente o método histórico. A teoria econômica keynesiana continua sendo um bastião dessa forma de pensamento e pesquisa, embora nem todos os economistas keynesianos se deem conta disso. Mais recentemente, metodologistas econômicos como Uskali Maki $(1992,2002)$ com seu "método do isolamento em economia", e Tony Lawson $(1997,2003)$ com seu "realismo ontológico", vêm trabalhando em uma abordagem realista à teoria econômica que guarda relação com o que estou propondo aqui. Por outro lado, ideias que opõem explicações sociais a explicações individualistas ou sistemas abertos a sistemas fechados (Sheila Dow, 1996; Victoria Chick, 2004) estão diretamente relacionadas a minhas concepções.

\section{O OBJETO DA ECONOMIA: OS SISTEMAS ECONÔMICOS}

A economia é uma ciência substantiva que tem por objeto os sistemas econômicos, suas propriedades de estabilização, crescimento e distribuição. O objetivo é entender e explicar esses sistemas e prever seus desenvolvimentos, de tal forma que os agentes econômicos possam ou se ajustar a eles, ou influenciá-los por meio da política econômica. O estudo da história do pensamento econômico mostra que todas as principais escolas econômicas objetivam chegar à compreensão dos sistemas econômicos. Assim, o método adequado à economia é o método empírico, mais especificamente, o método histórico-dedutivo. Isso não significa que os economistas não devam usar também o método hipotético-dedutivo, mas que devem reservá-lo para a elaboração dos conceitos e ferramentas que utilizam para compreender os sistemas econômicos coordenados pelo mercado. O método históricodedutivo é "histórico" porque parte da observação da realidade empírica e procura generalizar a partir dela; é "abdutivo" porque desenvolve hipóteses baseadas em algumas observações; é "dedutivo" porque envolve uma série de deduções; e, finalmente, é indutivo porque testa as hipóteses sempre que possível, com ferramentas econométricas que são intrinsecamente indutivas. O objetivo é chegar a uma visão geral do sistema econômico; é formular modelos históricos que relacionam regularidades e tendências observadas de modo a formar uma teoria..$^{9}$ A alternativa é

\footnotetext{
${ }^{9}$ Abdução é um conceito proposto por Peirce (1878), que via o raciocínio lógico como sendo composto não apenas de indução e dedução, mas também de abdução. A abdução, que Peirce também chamou de "método da hipótese", é o processo de inferir uma hipótese partindo de um ou de alguns fatos - fatos que serão mais interessantes na medida em que forem surpreendentes para o pesquisador. Assim, como Hands (2001: 224) observa, a "abdução é a matéria de qualquer 'insight' [...] é uma noção relativamente frouxa de inferência”. Abdução é parte da lógica da descoberta. Como diz Chong Ho Yu (2005: 7), "para Peirce, o progresso da ciência depende da observação dos fatos corretos por mentes providas das ideias apropriadas. Definitivamente, o julgamento intuitivo feito por um intelectual é diferente daquele feito por um estudante do ensino médio".
} 
acreditar que a economia é uma teoria da escolha, ou uma caixa de ferramentas para entender os sistemas de mercado, mas nesse caso ela deixa de ser uma ciência substantiva para se tornar uma ciência metodológica; deixa de ser a ciência da produção e distribuição para se tornar um mero conjunto de ferramentas a serem utilizadas na análise dos sistemas econômicos sobre os quais nossas ciências nada dizem. Essa alternativa deixa de incluir o objetivo fundamental da análise econômica: fornecer uma teoria que explique como os sistemas econômicos podem ser relativamente estáveis embora em permanente mudança, como alocam recursos e distribuem renda, e como crescem. Os sistemas econômicos são sistemas sociais ou históricos baseados no trabalho, coordenados pelo mercado e outras instituições, e orientados para a produção de riqueza. Os sistemas econômicos não existem per $s e$, são sistemas sociais, vistos da perspectiva econômica. Cada ciência social estuda os sistemas sociais de uma perspectiva particular, mas o objeto de estudo é o mesmo. É por isso que as instituições, em particular as instituições políticas, são também tão importantes em economia. Os economistas clássicos ou políticos não tinham dúvidas de que seu objeto era o sistema econômico, e estavam cientes das limitações que tal definição impunha a suas pesquisas. Os economistas neoclássicos mudaram gradualmente essa visão. Como seu modelo básico de sistema econômico - o modelo do equilíbrio geral - era radicalmente abstrato, tinha pouca utilidade para explicar as realidades econômicas concretas. Em compensação, porém, o método hipotético-dedutivo mostrou-se útil na construção de uma série de conceitos e modelos parciais que estão presentes na microeconomia. ${ }^{10}$

A economia não pretende estudar todos os tipos de sistemas econômicos, mas apenas os sistemas modernos - os sistemas capitalistas - que se baseiam em duas instituições econômicas principais: mercados e dinheiro. Ambos são instituições socialmente construidas que permitem a troca de bens e a correspondente divisão do trabalho, e determinam a alocação de recursos e a distribuição de renda. Em todos os países, os mercados e o dinheiro são regulados pelo Estado, e internacionalmente por organizações como a OMC (Organização Mundial do Comércio). Como são construídos socialmente, os sistemas econômicos têm objetivos que estão relacionados aos objetivos políticos da sociedade. Refletindo os objetivos políticos que as sociedades modernas foram gradualmente definindo, o princípio ou lógica subjacente aos modernos sistemas econômicos não é apenas a sobrevivência ou a estabilidade, mas também o bem-estar de seus componentes individuais e a sustentabilidade ambiental. A economia deve explicar, em primeiro lugar, como os sistemas reais alocam recursos escassos; em segundo lugar, como eles permanecem relativamente estáveis através de todo o ciclo econômico; em terceiro lugar, como se desenvolvem; e quarto, como distribuem a renda gerada. A microeconomia clássi-

\footnotetext{
${ }^{10}$ Refiro-me, por exemplo, às curvas de oferta e demanda, aos conceitos marginais, aos conceitos de elasticidade, aos conceitos de curto e longo prazo etc. - em suma, a todas as ferramentas presentes na microeconomia. Modelos que definem falhas de mercado também se inserem nessa categoria.
} 
ca e a marshalliana ofereceram as respostas essenciais para o primeiro problema; a macroeconomia keynesiana, para o segundo; a economia política clássica, para o terceiro e o quarto. Mas enquanto a teoria econômica clássica e a keynesiana ofereceram respostas sobre como os sistemas econômicos reais funcionam, a teoria econômica neoclássica não o fez. Seu modelo central - o modelo do equilíbrio geral - é um modelo de mercado sem dinheiro e outras instituições que são essenciais para uma visão minimamente abrangente do todo. A teoria de como os sistemas econômicos crescem no tempo foi desenvolvida pelos economistas clássicos, particularmente Smith e Marx. ${ }^{11}$ Ambos entendiam que o objeto da economia - ou da "economia política", como eles denominavam a disciplina em sua época - era o sistema capitalista. Eles estavam interessados em compreender a lógica subjacente à maneira pela qual as economias capitalistas alocavam recursos, que ambos identificavam como a teoria do valor-trabalho e dos preços, e em compreender como elas se desenvolviam: Smith atribuía à divisão do trabalho e à acumulação de capital, e Marx à mesma acumulação de capital e ao progresso tecnológico. A primeira teoria geral de como os sistemas econômicos reais efetivamente funcionam no curto prazo foi formulada por Keynes. Ele estava preocupado em compreender o sistema econômico real, mas da perspectiva da estabilidade e do pleno emprego a curto prazo, não da perspectiva do crescimento. Enquanto isso, a escola neoclássica ou marginalista tentava construir uma alternativa microeconômica à escola clássica e ao que seria a teoria keynesiana, mas só conseguiu chegar a uma visão extremamente abstrata de um sistema de mercado que, embora tendo qualidades heurísticas, tem pouca relação com os sistemas econômicos capitalistas reais.

Se excluirmos da microeconomia a teoria da utilidade marginal do valor e o modelo do equilíbrio geral - dois modelos que pretendem descrever a realidade e, assim, constituem o núcleo do pensamento neoclássico - a microeconomia será uma ciência metodológica, tal como a teoria dos jogos e a econometria. Isso se segue do argumento que adoto aqui. Se a teoria econômica neoclássica não foi capaz de explicar e prever os sistemas econômicos usando um método não adequado às ciências substantivas, ela deve ser descartada. Mas se essa escola foi capaz de desenvolver ferramentas para analisar os mercados e auxiliar na tomada de decisões econômicas, não há razão para não utilizar seus aspectos positivos. Limitada a esse papel de ferramenta, a microeconomia neoclássica continuou sendo relevante. E, como já acontece com outras ciências metodológicas como a econometria ou a teoria dos jogos, não se exigirá dela que seja realista. A economia deve ser realista, deve explicar e prever o comportamento dos sistemas econômicos; as ferramentas precisam apenas ser consistentes e úteis.

\footnotetext{
${ }^{11}$ Isso naturalmente não impede que certos marxistas desenvolvam métodos totalmente hipotéticodedutivos. Esses são meros desvios, assim como a teoria econômica neoclássica é um desvio da teoria econômica de Adam Smith.
} 


\section{O MÉTODO HISTÓRICO-DEDUTIVO E A ABORDAGEM DO FATO HISTÓRICO NOVO}

Para estudar sistemas econômicos complexos e em mudança, o método científico adequado é o método histórico-dedutivo. É histórico, porque se baseia na observação da realidade econômica histórica, onde cada evento é único, mas está suficientemente relacionado a outros eventos econômicos, de tal forma que é possível buscar regularidades ou pelo menos tendências. Nem sempre serão encontradas regularidades. Na verdade, nem todas as explicações científicas as exigem. Não há "regularidades" no Big Bang, ou na Revolução Industrial; na economia, alguns objetos de estudo são frequentes, outros não, e outros acontecem apenas uma vez. ${ }^{12}$ Cada evento social ou econômico é único, e a regularidade só se materializa quando certos eventos que possuem semelhanças básicas tendem a se repetir num período de tempo. Em alguns casos, não podemos falar de regularidade, mas de "cumulatividade": mesmo quando tais eventos carecem de regularidade, seu aparecimento pode ser resultado da acumulação de vários fatores inter-relacionados, permitindo detectar uma tendência. ${ }^{13}$ Quando as regularidades se materializam, elas aparecem como eventos históricos relacionados às convenções ou instituições que lhes dão sentido e restringem sua regularidade. ${ }^{14}$ Assim, ao contrário do economista neoclássico que vê a economia como uma "ciência natural", essa abordagem histórica exige que o pesquisador inclua na realidade social e econômica que é objeto de seus modelos explicativos as convenções, rotinas ou instituições, como tão bem argumentaram Herbert Simon (1996) e Nelson e Winter (1982), porque essa realidade não é natural, mas criada pelo homem - é um artefato.

Em economia, como em qualquer outra ciência, é necessário observar os fatos econômicos - sobretudo os novos -, conectá-los aos outros fatos sociais e políticos e desenvolver novas hipóteses explicativas e de previsão; em um segundo estágio, elaborar modelos tão simples quanto possível; e, finalmente, voltar para a realidade e buscar comprovação empírica. A formalização é um mero expediente para facilitar - nunca para complicar - a comunicação do modelo. ${ }^{15} \mathrm{E}$ também para torná-lo mais preciso quando isto é possível. No processo de desenvolvimento de uma teoria,

\footnotetext{
${ }^{12}$ Devo essa observação sobre as regularidades a Ramón Garcia Fernández.

${ }^{13}$ Devo essa observação sobre a cumulatividade dos eventos a Marcos Ribeiro Ferrari.

${ }^{14}$ Sabemos a importância que Keynes atribuía às convenções. A partir dos anos 1980, as instituições se tornaram algo indispensável nas ciências sociais. Economistas e outros cientistas sociais perceberam que era impossível compreender a sociedade e a economia sem levar em conta as leis formais e informais.

${ }^{15} \mathrm{O}$ pressuposto de que a formalização é uma condição indispensável do pensamento econômico é adotado até mesmo pelos economistas neoclássicos que não se limitam a fazer ciência normal. É o que acontece com Krugman (1999), por exemplo, que não hesitou em afirmar que o verdadeiro trabalho científico de inserir externalidades na teoria do desenvolvimento econômico através do modelo do big push [grande empurrão] - um dos modelos centrais da teoria do desenvolvimento econômico - não foi
} 
primeiro o economista, observando as realidades econômicas que o cercam, terá uma intuição. Em segundo lugar, ele submeterá sua intuição original ao conhecimento que já possui dos processos econômicos, usando as ferramentas e modelos à sua disposição. Mas, caso sua visão envolva uma verdadeira novidade, ele logo vai perceber que terá de desenvolver novos conceitos e ferramentas adicionais para dar suporte à nova teoria (Schumpeter, 1949; Meek, 1967). Num primeiro momento, ele abduzirá, a partir da observação de realidade, uma hipótese provisória; mas logo terá de recorrer ao raciocínio dedutivo; e por fim, terá de, indutivamente, voltar aos fatos para testar econometricamente se eles confirmam a teoria; a econometria é essencialmente um exercício indutivo. Seu objetivo será compreender o sistema econômico real como um todo. Esse sistema econômico pode ser o sistema macroeconômico brasileiro, o sistema monetário europeu ou o sistema de crescimento chinês. O essencial é compreender a lógica ou os princípios subjacentes que organizam esse sistema, compreender como seus vários elementos estão interconectados e variam um em relação ao outro; e também ser capaz de prever suas tendências, e como o sistema mudará se certas políticas ou algumas instituições mais permanentes forem introduzidas. Nesse processo, abdução, dedução e indução serão métodos de inferência intrinsecamente complementares: cada um é impossível sem o outro. No entanto, enquanto o método hipotético-dedutivo corresponde ao tempo lógico, o método histórico-dedutivo trabalha com o tempo histórico. ${ }^{16}$

Usando principalmente o método histórico-dedutivo, o pesquisador sabe que a indução não leva a verdades definitivas, mas ele se satisfaz com os modelos abertos que consegue obter. Os fatos econômicos ou as relações econômicas ocorrem em um tempo histórico, estão permanentemente mudando e, assim, as generalizações que precisam ser feitas para desenvolver uma teoria devem ser limitadas e provisórias. As realidades complexas - os sistemas econômicos - exigem modelos abertos. ${ }^{17}$ Sua complexidade é muito maior do que supõe o modelo do equilíbrio geral. As variáveis potenciais são tão numerosas que muitas delas, embora relevantes, não podem ser formalmente incluídas no modelo. Por outro lado, reconhecendo as contradições existentes na realidade, os modelos devem ser parcialmente indeterminados. Grandes economistas usaram principalmente o método histórico, mas combinado em diferentes graus com o método hipotético. Às vezes, eles percebiam que essa prática levava a contradições, mas eram suficientemente grandes - e isso ocorreu tipicamente com Marx, Schumpeter e Keynes - para viver com suas

realizado por Rosenstein-Rodan (1943), que o criaram, mas por Murphy, Shleifer e Vishny (1989), que o formalizaram.

${ }^{16}$ Devo essa observação a Alain Herscovici.

${ }^{17}$ Esta visão da metodologia econômica foi particularmente desenvolvida por Sheila Dow (1996) e Victoria Chick (2004). A primeira define o sistema aberto como um sistema em que "nem todas as variáveis constitutivas e relações estruturais são conhecidas ou passíveis de serem conhecidas, e portanto os limites do sistema não são conhecidos nem passíveis de serem conhecidos” (1996: 14). 
contradições, em lugar de tentarem formular teorias abrangentes e absolutamente coerentes. $^{18}$

A partir do momento em que o economista desenvolve um modelo a partir de suas observações empíricas e da pesquisa econométrica, ele tentará reduzir o grau de incerteza intrínseca desse modelo por meio da busca de microfundamentos racionais. Essa busca dá consistência ao modelo. Essa estratégia heurística é mais ou menos semelhante à distinção metodológica feita por Max Weber (1922: cap. 1) entre compreensão e explicação. O cientista social deve tentar primeiro entender os fenômenos sociais e econômicos, encontrar suas regularidades e suas características distintivas, adotando uma análise essencialmente histórica que o leve a propor alguns fatos estilizados e suas conexões lógicas. Em seguida, porém, ou até ao mesmo tempo, ele deve explicar, com motivações racionais, as relações de causa e efeito que foram empiricamente encontradas. Nesse caso, o pesquisador não deve deduzir as relações teóricas a priori, mas a posteriori, descobrindo os motivos racionais subjacentes. ${ }^{19}$

É importante não confundir o método histórico descrito nos parágrafos anteriores com a escola historicista alemã de Gustav Schmoller e Max Weber. É verdade que os historicistas não rejeitavam a teoria, mas viam estreitos limites para o desenvolvimento de modelos teóricos - limites que foram depois consideravelmente ampliados pela teoria macroeconômica keynesiana e kaleckiana. ${ }^{20}$ No entanto, há semelhanças significativas entre o método histórico-dedutivo apresentado aqui e o método histórico adotado por Max Weber (1906: 72). Ao estudar as leis econômicas, Weber não definiu "leis" no sentido estrito usado pelas ciências naturais, mas como "relações causais adequadas". O objetivo da economia política é "o conhecimento dos fenômenos históricos em sua concretude... as leis mais gerais, por serem mais desprovidas de conteúdo, são também as menos valiosas”. É necessário também não confundir o método histórico-dedutivo com a busca de uma

\footnotetext{
${ }^{18}$ Pensemos, por exemplo, em Schumpeter, que gostava de dizer que o modelo do equilíbrio geral era a maior conquista da teoria econômica, mas baseou sua própria teoria da inovação e do empresário na crítica do fluxo circular - uma simplificação daquele modelo.

${ }^{19}$ Habermas (1967: 19) estuda essa abordagem metodológica proposta por Weber e lembra que Weber começa seu livro de 1922 afirmando que: "a sociologia é uma ciência que pretende compreender interpretativamente a ação social para chegar assim a uma explicação causal de seu curso e de seus efeitos". E Habermas (1967: 19) resume a visão metodológica de Weber afirmando que: "Weber analisou particularmente a articulação entre explicação e compreensão [...] As teorias gerais possibilitam deduzir hipóteses relacionadas às regularidades empíricas. Essas leis hipotéticas têm uma função explicativa. Ao contrário dos processos naturais, porém, as regularidades da ação social têm a característica de serem compreensíveis. As ações sociais pertencem à classe das ações intencionais, que apreendemos ao reconstruir seu significado".

${ }^{20}$ Não acredito que Schumpeter (1959, vol. 3: 80) tenha sido injusto com Schmoller quando afirma que ele utilizava um aparelho conceitual mas "teorizava de forma deficiente". De acordo com a observação de Schefold (1987: 257), "o principal trabalho de Schmoller, o Grundrisse, continuava sendo bastante tradicional em sua parte teórica - o tratamento do valor e do preço não se afastava muito da teoria econômica neoclássica dominante".
} 
teoria da mudança econômica como proposto por Nelson e Winter (1982). A crítica principal que esses importantes economistas fazem à teoria econômica neoclássica é que ela não explica os processos de mudança econômica. Eles propõem assim substituí-la por uma teoria evolucionária - um produto importante das escolas de economia histórico-dedutivas. Minha crítica à teoria econômica neoclássica - a que estou desenvolvendo neste trabalho - não é de que ela seja estática, nem, como veremos, de que o pressuposto do homo economicus não seja realista, mas, partindo do pressuposto do comportamento racional egoísta, de que ela usa basicamente um método que é apropriado às ciências metodológicas e não às ciências substantivas; que ela tenta, a partir de algumas condições iniciais, deduzir modelos que devem explicar realidades econômicas complexas e em mudança.

O ponto de partida do método histórico-dedutivo em economia é o pressuposto dos mercados poderosos mas imperfeitos. Quando os mercados são perfeitos, eles são atemporais, e não há nada de novo a analisar e nenhuma política a ser proposta. Usando o método histórico-dedutivo e uma variedade dele que chamo de "método dos fatos históricos novos", o pesquisador partirá do pressuposto de que o conhecimento existente sobre uma determinada realidade econômica era razoavelmente satisfatório até o momento em que fatos históricos novos - progresso tecnológico, mudança institucional, grandes acontecimentos políticos, guerras - vieram a alterá-lo. Alterá-lo em que direção, em que grau? O uso da abordagem dos fatos históricos novos nos ajudará a responder a tais perguntas. A identificação do fato ou fatos novos será instrumental para o desenvolvimento de um novo modelo explicativo do sistema econômico em exame. O pesquisador não precisará partir do começo, mas apenas acrescentar ao seu modelo os fatos novos que alteraram a realidade. Assim, ele não será capaz de entender o processo de mudança econômica em si, mas será capaz de entender como o sistema econômico passou de um momento histórico para outro e de identificar as características peculiares da nova fase histórica ou da nova realidade histórica ou econômica. A detecção do fato novo pode se referir a um evento que não é exatamente novo: ele já existia há algum tempo, mas ainda não havia sido percebido. Quando um pesquisador descobre esse fato, ele se transforma em um fato novo na medida em que exige a modificação dos modelos explicativos existentes. No âmbito das ciências sociais, o fato novo dá origem ao problema a ser resolvido nos níveis científico e prático. Entendido nesses termos, o método do fato histórico novo está relacionado à abdução - ou "método da hipótese" - que começa com o pesquisador observando um evento surpreendente que provocará sua imaginação e o levará à formulação da hipótese. E, como já acontece com a abdução, não é um método pertencente à esfera da lógica da justificação, mas à lógica da descoberta.

O método usado pelos economistas clássicos para analisar a revolução capitalista ou o aparecimento das economias coordenadas pelo mercado, assim como o método originalmente empregado por Keynes para explicar as flutuações cíclicas e estabelecer as bases da macroeconomia, partia da observação de fatos históricos 
novos, que envolviam rupturas ou descontinuidades que exigiam o reconhecimento de novas regularidades, e implicavam a definição de novos conceitos e a análise das conexões lógicas entre as variáveis econômicas relevantes. Adam Smith reconheceu o início da Revolução Industrial e mudou o foco da análise econômica, do comércio para a produção; Marx compreendeu que a revolução capitalista era o fato histórico tectônico novo que estava mudando o mundo e fez uma análise inigualável do modo de produção capitalista; Keynes construiu a primeira teoria econômica completa baseada no método histórico-dedutivo ao escrever a Teoria Geral após a Primeira Guerra Mundial, o Tratado de Versalhes, a hiperinflação na Alemanha e na Europa central, e a Grande Depressão, que haviam mudado a economia mundial. Só depois de observar as novas regularidades e tendências que estavam emergindo e de desenvolver os novos conceitos é que esses grandes economistas foram capazes de ligar as variáveis e construir seus modelos. A contribuição de Keynes nesse campo é particularmente relevante porque, com a Teoria Geral, ele mostrou que, usando o método histórico-dedutivo, era possível formular um modelo abstrato e formal que, ao mesmo tempo, estava próximo da realidade econômica, era prático para orientar a política e suficientemente simples e geral para constituir uma contribuição definitiva à teoria econômica.

A validação das hipóteses desenvolvidas segundo o método histórico-dedutivo dependerá de pesquisa - geralmente da pesquisa econométrica. As ferramentas econométricas limitam-se à verificação de algumas características específicas de um problema muito mais amplo, e seus resultados são muitas vezes decepcionantes, na medida em que as causas e consequências não forem claramente diferenciadas, ou na medida em que as variáveis relevantes não forem consideradas. Para cada problema econômico, geralmente são encontradas evidências econométricas para justificar teorias opostas. Mas nenhuma dessas limitações deve nos impedir de usar as ferramentas econométricas. Ao contrário, se o método histórico-dedutivo deve partir da observação da realidade, essa observação pode ser reforçada pela econometria. Quando estão envolvidas séries históricas de dados, o pesquisador deve ou partir de suposições acerca dessas descontinuidades históricas a fim de fazer sentido, ou identificar a ocorrência de tais descontinuidades com o uso de métodos econométricos. ${ }^{21}$ De qualquer modo, a partir do momento em que forem identificados tanto o fato histórico novo quanto a descontinuidade, a análise econométrica subsequente terá de levá-los em estrita consideração.

Além dos testes econométricos, é importante testar o modelo em termos de sua utilização prática na previsão de resultados e na formulação da política econômica. Em termos teóricos, não há melhor validação para uma teoria econômica do que a possibilidade de dela derivar previsões confiáveis. Em termos pragmáticos, uma teoria é validada quando é possível deduzir políticas econômicas que se mostram

\footnotetext{
${ }^{21}$ Não devemos desconsiderar o fato de que, em alguns casos, uma mudança contínua pode eventualmente implicar também uma descontinuidade.
} 
eficazes. No Brasil, por exemplo, o Plano Real, que em 1994 acabou com a inflação crônica e elevada, baseava-se na teoria da inflação inercial que havia sido anteriormente desenvolvida por alguns economistas brasileiros. O sucesso do Plano Real em neutralizar a inflação foi uma validação da teoria.

\section{O MÉTODO HIPOTÉTICO-DEDUTIVO}

O método hipotético-dedutivo utilizado pela teoria neoclássica é essencialmente apriorístico. Ele assume que os agentes econômicos maximizam sua utilidade e, a partir desse simples pressuposto, combinado com outros como preferências estáveis, retornos decrescentes, informação perfeita etc., deduz lógica e matematicamente todo o seu modelo. Seu pressuposto interno próprio é que basta ter as condições iniciais definidas para saber quais serão as consequências. De acordo com Prigogine (1997), essa forma de determinismo metodológico é atemporal, implicando causalidade perfeita ou lógica. As variáveis econômicas são determinadas por condições iniciais. As irregularidades não previstas, oriundas dos processos históricos reais, são ignoradas: não há "dependência da trajetória" [path dependence]..$^{22}$

Usando esse método, os economistas neoclássicos primeiramente deduziram o modelo microeconômico; em segundo lugar, aplicaram-no ao crescimento econômico com o modelo de Solow, e, em terceiro lugar, chegaram ao modelo macroeconômico neoclássico (o "novo modelo clássico" de Robert Lucas), em que o modelo macroeconômico também se torna totalmente fechado e perfeitamente compatível com seus dois outros ramos. ${ }^{23}$ Com isso, a teoria econômica neoclássica oferece uma teoria econômica "completa" ou "abrangente" - micro e macro, estática e dinâmica - mas uma teoria com pouca aplicação. O modelo do equilíbrio geral ajuda a compreender como um sistema de mercado aloca recursos, mas é tão abstrato que carece de capacidade de previsão. O modelo de Solow nasceu de uma crítica ao modelo Harrod-Domar; sua maior conquista, na verdade, não foi mostrar que o progresso tecnológico é a chave do crescimento econômico, pois esse era um argumento central da escola clássica, mas apresentar um modelo de crescimento compatível com o equilíbrio geral. A alegação de que o grande "resíduo" encontrado nas regressões das equações de crescimento mede a contribuição da tecnologia ao crescimento econômico é discutível; a afirmação feita por econometristas ingênuos ao relacionarem o crescimento econômico com a variável $\mathrm{x}$ ou y, de que eles estão "usando o modelo de Solow" como teoria subjacente é apenas retórica: na verdade, eles estão apenas testando as hipóteses simples contidas em seus testes econométricos; a conclusão derivada do modelo de que "a tecnologia é mais importante do que

\footnotetext{
${ }^{22}$ Ver as ideias de Prigogine aplicadas à economia em Ferrari (2003).

${ }^{23}$ Entendo que o modelo do Ciclo Real de Negócios é apenas uma adaptação do Novo Modelo Clássico.
} 
a acumulação de capital para explicar o crescimento" é apenas tolice: ambas as variáveis são fundamentais, e estão tão interligadas que é impossível separar uma da outra. O movo modelo macroeconômico clássico ganhou alguma aceitação após ter sido apresentado porque alcançou em nível macro aquilo que o modelo de Solow havia alcançado no nível do crescimento: consistência. No entanto, logo se evidenciou sua incapacidade de explicar e prever o desempenho macroeconômico, e tanto os responsáveis pelos bancos centrais como os analistas econômicos o abandonaram, juntamente com sua correspondente política de metas monetárias. ${ }^{24}$

Esse fraco desempenho da teoria econômica neoclássica em explicar e prever os sistemas econômicos está associado ao papel que ela atribuiu ao homo economicus. Mas quando estudamos o comportamento econômico, embora outras motivações possam ser relevantes, a hipótese racional ou egoísta aplica-se razoavelmente. Por que, então, é o pressuposto do homo economicus que provoca o fracasso da teoria econômica neoclássica? Não porque esse pressuposto seja falso, mas porque é impossivel deduzir o sistema econômico de um pressuposto tão simples; porque realidades complexas e em mudança não podem ser deduzidas apenas das condições iniciais. Os modelos dedutivos derivados desse pressuposto não conseguem necessariamente abranger a realidade presente nos sistemas econômicos. $\mathrm{Na}$ verdade, os três modelos que formam o núcleo do pensamento neoclássico (equilíbrio geral, modelo de Solow e modelo de Lucas) estão comprometidos com a consistência lógica, não com a correspondência com a realidade. As numerosas e persistentes contradições ou anomalias não levam à rejeição dos modelos; o cinto protetor que cerca a teoria central é absoluto, porque não se baseia nos critérios de correspondência e de previsibilidade, mas em sua coerência lógica. Todas as anomalias, como o poder monopolista, as externalidades, a dependência da trajetória, a assimetria da informação e o risco moral, são definidas de maneira elegante e vistas somente como fatores perturbadores ou falhas de mercado de um modelo que é internamente consistente. As instituições, até mesmo o dinheiro, foram simplesmente excluídas do modo neoclássico central. O dinheiro é visto como "neutro”, ou seja, não tendo consequências sobre as variáveis reais. Quando finalmente as instituições foram reconhecidas, elas foram também abstratamente "deduzidas" do conceito de custos de transação, em lugar de serem entendidas como realidades históricas que estão em permanente desenvolvimento, à medida que as sociedades regulam o comportamento social.

Economistas com uma forte demanda interna por consistência e precisão, e que se sentem particularmente atraídos pela matemática, costumam ficar fascinados quando apresentados a uma teoria que consegue ser clara, abrangente e matematicamente precisa - algo que é possível na medida em que é elaborada de acordo com o modo hipotético-dedutivo. Desse modo, eles acreditam que a economia se

\footnotetext{
${ }^{24}$ O perigo envolvido no que Schumpeter chamou de "vício ricardiano" está presente aqui.
} 
torna plenamente formal e, portanto, "científica", como se ciência e formalização fossem a mesma coisa. A crença de Stuart Mill de que seria possível comprovar a teoria econômica desenvolvida de acordo com o método hipotético-dedutivo continua a assombrar a economia, em vista das realidades econômicas complexas e em mudança. Atualmente, essa é a principal razão para a crescente irrelevância da teoria macroeconômica pretensamente científica das expectativas racionais que é ensinada nos cursos de pós-graduação das universidades. Adotando o método hipotético-dedutivo e seu modelo supremo - o equilíbrio geral - os economistas tentam analisar sistemas econômicos reais. Eles partem daí, e então, passo a passo, relaxam os pressupostos correspondentes até o ponto em que se aproximariam do mundo real. Esse procedimento, entretanto, envolve uma trajetória longa, cansativa e pouco natural. Os economistas que tentam adotá-la logo percebem que é uma trajetória perigosa: eles se arriscam a acabar sem nenhum modelo. Assim, voltam a cair em algum tipo de equilíbrio geral que não diz nada sobre o sistema econômico real em estudo, a não ser que os mercados são mecanismos institucionais de alocação de recursos excelentes mas incompletos. Ou se limitam a fazer estudos econométricos específicos que podem fornecer informações relevantes, mas que não substituem a análise macro do sistema econômico.

Para os economistas neoclássicos, a legitimidade de sua ciência está relacionada à sua formalização, que, por sua vez, depende da adoção de um método dedutivo. O que estou identificando como uso abusivo da matemática é visto por eles como prova de sua proficiência científica pessoal. Só é possível reduzir totalmente a economia ao raciocínio matemático quando se adota um individualismo metodológico radical, e se deduzem todos os modelos de um microfundamento básico - a plena racionalidade dos agentes. A alegação de Debreu de que "o raciocínio dedutivo sobre os fenômenos sociais encorajava o uso da matemática... porque dois de seus conceitos fundamentais, as commodities e os preços, são quantificados de uma forma peculiar assim que as unidades de medida são escolhidas...”, só explica em parte o uso da matemática na economia. Mirowski (1991: 145, 153, 155), que citou Debreu, rejeita o abuso da matemática na economia, criticando acertadamente a implícita "noção de que as commodities exibem um isomorfismo natural em relação a um espaço vetorial euclidiano real", e salienta que a matematização da economia deveria ser limitada, porque as "simetrias e invariâncias existentes nas atividades do mercado" devem ser explicadas "por meio da instrumentalidade das instituições sociais". Mas Debreu e seu crítico deixam de perceber que a razão central para a matematização da economia não está na natureza das commodities, mas na natureza do método escolhido: o método hipotético-dedutivo. Uma vez que o economista decida derivar logicamente toda a análise econômica do pressuposto do homo economicus, juntamente com alguns outros pressupostos como a lei dos retornos decrescentes, a análise pode ser totalmente reduzida à matemática. 


\section{A CRÍTICA PRINCIPAL}

A teoria econômica neoclássica geralmente se distingue da teoria econômica clássica pela substituição do valor da utilidade marginal ou de seu caráter "marginalista” pela teoria do valor-trabalho. Esse critério de classificação é válido, mas segundo a abordagem deste estudo, a distinção essencial é metodológica. A escola clássica utilizou principalmente o método histórico-dedutivo, enquanto a neoclássica, o método hipotético-dedutivo. Embora os economistas saibam que os agentes econômicos nem sempre agem racionalmente para maximizar sua utilidade, apesar do fato de o conceito de racionalidade limitada de Herbert Simon ser bem demonstrado, não obstante todas as recentes pesquisas experimentais demonstrarem empiricamente que o comportamento dos agentes não segue a lógica racional que a teoria econômica neoclássica atribui aos agentes econômicos, a teoria econômica neoclássica não rejeita o pressuposto do homo economicus porque toda sua estrutura teórica depende da racionalidade dos agentes. ${ }^{25}$ Esse é o pressuposto que lhe permite construir seu modelo central. Quando essa racionalidade é empiricamente rejeitada, o método hipotético-dedutivo se torna inútil. Agentes ambíguos e contraditórios ou racionalidade limitada não permitem deduzir teorias.

Minha crítica central à teoria econômica neoclássica, entretanto, não é quanto à racionalidade dos agentes econômicos, mas quanto ao uso que foi feito desse pressuposto. Ainda que a falta dessa racionalidade esteja amplamente demonstrada pelas pesquisas econômicas comportamentais, o que estou propondo não é substituir o homo economicus por um indivíduo mais realista, mas atribuir a ele um papel mais modesto - explicar a posteriori a racionalidade dos modelos derivados da observação da realidade - usando ao mesmo tempo principalmente o método histórico-dedutivo. Minha crítica é quanto ao caráter dedutivo radical da teoria econômica neoclássica, quanto à sua tentativa de chegar a modelos a partir de umas poucas condições iniciais, e também quanto à substituição dos critérios de correspondência e previsibilidade pela consistência. Como a economia é uma ciência substantiva, o raciocínio sobre ela deve partir da observação de fatos históricos, não de um modelo abstrato de homem. O economista deve generalizar modelos a partir dessas observações históricas. A busca de motivos racionais não é abandonada, mas ela virá para explicar o que foi observado, para compreender por que os comportamentos econômicos observados são racionais ou, pelo menos, razoáveis.

Os economistas neoclássicos em parte percebem isso. Essa é a razão pela qual eles se apropriam de ideias e modelos que não têm microfundamentos, mas são úteis. É por isso que alguns analistas dizem que o pensamento econômico dominante não

\footnotetext{
${ }^{25}$ Herbert Simon (1957) mostrou que a racionalidade econômica é "limitada”, e que os agentes econômicos são capazes de obter resultados "satisfatórios" [satisficing] em lugar de resultados máximos. Isso é compatível com a microeconomia de Keynes subjacente à Teoria Geral, que já é uma microeconomia da escolha e não da maximização.
} 
é mais neoclássico. De fato, quando economistas que se proclamam neoclássicos precisam fazer análises econômicas objetivas e apresentar políticas, eles geralmente se tornam pragmáticos e se esquecem dos princípios neoclássicos. Assim, ao contrário do que acontece com os modelos econômicos clássicos e keynesianos, simples e abertos, os modelos neoclássicos, complexos e formalizados, são de pouca utilidade para os analistas e formuladores de políticas. Eles ou são excessivamente gerais quando tentam ser científicos e prever o comportamento usando o método hipotético-dedutivo, ou mudam desse método para a esfera normativa, e opõem "regras a critérios" ou afirmam a óbvia importância da credibilidade.

Apesar do fracasso da teoria econômica neoclássica em analisar os sistemas econômicos reais, o pensamento econômico dominante ou ortodoxo convencional continua sendo neoclássico, porque usa um método essencialmente hipotético-dedutivo. ${ }^{26}$ Mas não é mais apenas neoclássico. As anomalias foram tantas, e as contribuições de outras áreas - como a economia evolucionária, a economia neoschumpeteriana, a economia experimental, a psicologia econômica, a teoria dos jogos, ou a econometria aplicada - foram tão significativas que, apesar de incompatíveis com o pensamento neoclássico, elas foram incorporadas à corrente dominante, tal como havia acontecido anteriormente com as ideias keynesianas. É por isso que alguns analistas estão sugerindo atualmente que a corrente dominante não é mais neoclássica, na medida em que está ficando cada vez mais distante dos principais dogmas dessa doutrina econômica, a saber, racionalidade, egoísmo e equilíbrio (Colander, Holt e Rosser, 2004; Lawson, 2005). É verdade que a teoria econômica convencional sofre mudanças constantes, e que seus partidários mais brilhantes e mais pragmáticos se esforçam para adaptá-la à realidade. Na maioria dos casos, em lugar de discutir seus fundamentos teóricos, eles simplesmente desenvolvem suas análises e pesquisas independentemente do núcleo neoclássico. Em outras palavras, profissionais competentes são suficientemente realistas para usar modelos que carecem dos microfundamentos exigidos pela teoria econômica neoclássica. Em macroeconomia, por exemplo, a regra de Taylor, que é hoje amplamente usada, é apenas uma regra prática engenhosa que emergiu da observação do comportamento efetivo dos responsáveis pelos bancos centrais. Nada está mais longe de um verdadeiro método hipotético-dedutivo neoclássico baseado em microfundamentos, mas isso não impediu economistas neoclássicos de adicionar à regra de Taylor as expectativas racionais, a fim de tornar a regra compatível com seu modelo geral. Outro exemplo é a introdução da teoria dos jogos em manuais de microeconomia. Foi um grande avanço, mas a teoria dos jogos é na verdade uma

\footnotetext{
${ }^{26}$ Isso não significa que os economistas neoclássicos não tenham oferecido contribuições positivas. Mas provavelmente a mais relevante de todas - a teoria das expectativas adaptativas de Friedman - só foi possível na medida em que Milton Friedman adotou uma abordagem histórica ou empírico-dedutiva, e buscou os microfundamentos a posteriori, não a priori como acontece quando o raciocínio é predominantemente hipotético-dedutivo.
} 
alternativa, não um complemento, à otimização neoclássica; a teoria dos jogos é parte da teoria geral das decisões; envolve escolha; a otimização supõe apenas um caminho, o caminho ideal. É uma ciência metodológica, uma teoria da tomada de decisões estratégicas em situações de incerteza, enquanto, na pura teoria neoclássica, não há espaço para a tomada de decisões: os agentes sempre maximizam, sempre escolhem a alternativa ideal. No entanto, ela foi significativamente incorporada aos livros de microeconomia, indicando que, se liberarmos a microeconomia neoclássica de seus componentes substantivos (teoria do valor-utilidade e equilíbrio geral), teremos também uma ciência metodológica facilitando a explicação e a tomada de decisões em sistemas de mercado.

Por que não determinamos os microfundamentos da teoria macroeconômica - o Santo Graal dos economistas neoclássicos - de modo a ter um único modelo econômico abrangente? Quando se adota principalmente o método histórico-dedutivo, essa busca se torna irrelevante. Os microfundamentos só são relevantes para as teorias econômicas que usam o método hipotético-dedutivo. No caso de uma abordagem histórico-dedutiva, os microfundamentos ou, mais precisamente, os motivos racionais, podem e devem ser buscados, mas a posteriori - para explicar o que foi observado, não para definir como a realidade é/deveria ser. Seus três ramos - a microeconomia clássica, a macroeconomia e a macroeconomia do desenvolvimento - já estão unificados, na medida em que lidam com o mesmo sistema econômico e são razoavelmente coerentes entre si. Como no caso da microeconomia neoclássica, a microeconomia clássica é aqui entendida como a teoria dos preços e da alocação de recursos, ou a teoria que prevê preços e quantidades. A diferença em relação à microeconomia neoclássica não é a notável análise formal que Marshall faz dos mercados e seu modelo de equilíbrio parcial, mas a teoria subjetiva do valor e do modelo do equilíbrio geral. Três ramos envolvem grandes esforços dedutivos, mas como eles são produto do método histórico-dedutivo, seus modelos abertos estão permanentemente adaptados a uma realidade em mudança.

Bresser-Pereira e Lima (1996) ofereceram uma resposta semelhante a essa, na medida em que afirmaram que micro e macroeconomia não podem ser reduzidas uma à outra, porque utilizam métodos diferentes. ${ }^{27}$ Neste trabalho, estou dando um passo à frente no argumento. A teoria econômica já está razoavelmente unificada, na medida em que seus três ramos usam o mesmo método histórico-dedutivo e seu objetivo é compreender os sistemas econômicos capitalistas contemporâneos. Digo "razoavelmente unificada" porque essa unificação é necessariamente frouxa, tendo

\footnotetext{
${ }^{27}$ Desenvolvi inicialmente essa ideia em um trabalho que, entretanto, acabou apenas como esboço (Bresser-Pereira e Lima, 1996). Além de ampliar a discussão dos dois métodos, no presente trabalho adoto termos mais apropriados, substituindo "histórico-indutivo" por "histórico-dedutivo", e "lógicodedutivo" por "hipotético-dedutivo". Elimino somente um elemento tautológico que prejudicava a terminologia anterior; além disso, esclareço que o método histórico a que estou me referindo é dedutivo, como todo processo de construção de teorias.
} 
em vista a complexidade do tema e os diferentes métodos históricos utilizados pelos pesquisadores.

\section{O NÚCLEO DA TEORIA ECONÔMICA}

A conclusão que nasce da discussão das seções anteriores é que o verdadeiro núcleo da teoria econômica não é formado pela tríade neoclássica (equilíbrio geral, modelo de crescimento de Solow e novo modelo macroeconômico clássico), mas pelas contribuições das escolas clássica e keynesiana - as duas escolas de pensamento econômico que usam basicamente o método histórico-dedutivo. A escola clássica contribuiu com sua teoria microeconômica ou teoria dos preços e da distribuição ${ }^{28}$, e com sua teoria do crescimento baseado na acumulação de capital e no progresso técnico; a escola keynesiana, com a macroeconomia. Fazem parte desse núcleo, mas de forma subsidiária, as contribuições, no passado, da escola histórica alemã, da escola institucionalista norte-americana e da escola da economia do desenvolvimento (na qual incluo a escola estruturalista latino-americana) e, no presente, da economia evolucionária e institucional. A teoria econômica clássica desenvolveu uma microeconomia que explicava os preços e a alocação de recursos pelo mercado e, principalmente, uma análise de longo prazo do sistema capitalista, seu caráter inerentemente instável mas dinâmico. Smith e Marx foram figuraschave dessa escola. A teoria econômica keynesiana ofereceu uma forma operacional e de curto prazo para analisar os sistemas monetários capitalistas. Nos anos 1970, a teoria econômica keynesiana perdeu importância na academia e no ensino de mestrado para a teoria macroeconômica neoclássica. Ela não perdeu importância "porque a curva de Philips não serviu", mas por razões ideológicas (a onda neoliberal que então se iniciava tinha a teoria econômica neoclássica como sua ferramenta acadêmica) aliadas a razões pseudocientíficas: a possibilidade de reduzir a teoria econômica neoclássica a uma formalização matemática total - algo impossível quando o modelo é historicamente derivado, como é o caso da macroeconomia keynesiana. Mas a teoria econômica keynesiana continuou a ser praticada em toda parte por analistas e formuladores de políticas, na medida em que seus atributos analíticos e de política fornecem previsibilidade e orientam políticas efetivas.

Assim, o verdadeiro núcleo da teoria econômica relevante - da ciência que é efetivamente adotada pelos economistas ao analisarem sistemas econômicos e proporem políticas - é a microeconomia clássica apoiada sobre o valor-trabalho e sobre a tendência à equalização das taxas de lucro, a teoria clássica do desenvolvimento capitalista completada por Schumpeter, a teoria econômica dos pioneiros desenvol-

\footnotetext{
${ }^{28}$ À qual ofereci uma análise alternativa, mantendo a taxa de lucro constante a longo prazo, e fazendo a taxa de salários, o resíduo, crescer com o aumento da produtividade e o tipo de progresso técnico (Bresser-Pereira, 1986).
} 
vimentos, e a macroeconomia keynesiana. A esse núcleo, é legítimo adicionar as contribuições da escola neoclássica à microeconomia, particularmente a genial contribuição de Marshall à compreensão dos mercados, excluindo-se, porém, a teoria subjetiva ou teoria da utilidade marginal do valor (que obviamente não é necessária para explicar a curva de demanda); para compreendermos como em um sistema econômico se formam os preços, a teoria do valor-trabalho tem maior capacidade explicativa. Devemos também excluir do núcleo da teoria econômica o modelo do equilíbrio geral, não apenas porque é competitivo com o modelo de equilíbrio parcial de Marshall, muito mais razoável útil, mas principalmente porque transmite a falsa ideia de perfeição e eficiência dos mercados que, em lugar de facilitar, prejudica o raciocínio econômico sobre os sistemas econômicos reais. Não é, entretanto, necessário deixar fora do núcleo da teoria econômica um grande número de modelos específicos desenvolvidos por economistas neoclássicos (ou economistas com formação neoclássica) que definem falhas de mercado - muitos deles modelos inteligentes e perspicazes que tornaram seus autores merecedores de prêmios e reconhecimento. ${ }^{29}$ Nesse caso, porém, devemos lembrar que esses economistas tiveram sucesso em desenvolver seus modelos ad hoc partindo da observação empírica da falha de mercado. Essas contribuições fazem parte da caixa de ferramentas que complementa a análise histórico-dedutiva dos sistemas econômicos.

Outra forma de ver a microeconomia marshalliana é considerá-la como o núcleo de uma segunda teoria econômica - uma teoria da escolha nos mercados e uma teoria para se analisarem mercados. Nesse caso, a microeconomia seria uma ciência metodológica. Seria ou uma ciência metodológica autônoma, ou parte de uma ciência mais ampla, a teoria geral da tomada de decisões, da qual a teoria dos jogos seria a outra parte principal. Em ambos os casos, poderia ser chamada de "microeconomia da escolha" ou "microeconomia da decisão". Essa alternativa (assim como a opção anterior de considerar essa esfera intelectual como uma parte complementar da microeconomia clássica) é uma conclusão lógica da distinção entre ciências substantivas e ciências metodológicas e da afirmação de que somente estas últimas deveriam usar primordialmente o método hipotético-dedutivo. Dadas essas premissas, cheguei a essa conclusão lógica, que é de certo modo confirmada pelo fato de que os economistas costumam encarar sua ciência não apenas como uma análise e explicação de sistemas econômicos, mas também como uma “caixa de ferramentas". Essa foi, por exemplo, a definição clássica de economia dada por Lionel Robins (1932): uma teoria da escolha. Foi também confirmada pelo fato de que, a partir da década de 1970, a teoria dos jogos foi incluída nos manuais de microeconomia. Muito antes, como nos conta Jürgen Habermas (1967 [1988]: 50-51), essa visão já havia sido bem discutida por Von Kempski e principalmente por G. Gäfgen:

\footnotetext{
${ }^{29}$ Penso, por exemplo, em modelos como o “mercado de limões" de Akerloff.
} 
A interpretação de Von Kempski da pura teoria econômica com a ajuda de um esquema de ação em termos de máximas puras já pode ser vista como uma tentativa de interpretar a teoria econômica em termos da lógica da decisão"... Gäfgen apresentou uma análise da lógica da importância econômica das ações racionais que, seguindo a teoria matemática dos jogos desenvolvida por Von Neumann e Morgenstern, incorpora sistematicamente a teoria econômica em uma teoria geral da ação estratégica.

Em lugar de descrever o comportamento real dos agentes econômicos no contexto de um sistema econômico, Gäfgen entendia que "o cálculo está envolvido apenas com a ação estratégica que leva de uma situação, constituída do sujeito atuante e seu ambiente relevante, a uma nova situação, por meio da aplicação de uma máxima definida de decisão e um sistema de valores". Mas como Habermas salienta, esse tipo de procedimento científico não é compatível com uma ciência empírico-dedutiva, cujas hipóteses devem ser testadas:

[Von Kempski] ignora a questão de saber se é possível equiparar as ciências normativo-analíticas e as ciências empírico-analíticas da ação social [ou ciências hipotético-dedutivas e histórico-dedutivas, em minha terminologia]. Ciências cujas teorias incorporam pressupostos básicos referentes à ação idealizada trabalham de modo normativo-analítico. Essas hipóteses sobre ação em termos de máximas puras não têm o caráter de hipóteses condicionais, e, portanto, não são empiricamente verificáveis; sua validade é hipoteticamente incondicional e, assim, estabelecem o sentido da possível validade do conhecimento normativo-analítico.

De acordo com essa alternativa, o núcleo da teoria econômica continua a ser a teoria econômica e a teoria macroeconômica keynesiana na medida em que são produto da análise empírico-dedutiva e formulam hipóteses refutáveis ou falseáveis - hipóteses a serem testadas -, mas acrescentamos à lista das ciências metodológicas associadas à economia (econometria e teoria dos jogos) a microeconomia da escolha.

\section{CONCLUSÃO}

Resumindo, minha afirmação central neste trabalho é que, por ser uma ciência social substantiva que visa a explicar e prever sistemas econômicos complexos, a economia deveria usar principalmente o método histórico-dedutivo, e não o hipotético-dedutivo, que é adequado às ciências metodológicas. As ciências substantivas têm em seu critério de verdade a adequação das teorias à realidade, ou sua capacidade de previsão para orientar a ação - um critério que só pode ser razoavelmente satisfeito se o pesquisador partir da observação da realidade, desenvolver sua teoria e voltar para a realidade para testar o modelo. Por outro lado, nas ciências metodológicas, o critério de verdade é apenas a consistência lógica. 
A ciência econômica trabalha, portanto, com dois métodos, mas, como ciência social, seu método principal é histórico-dedutivo. Suas maiores realizações foram obtidas por economistas clássicos e keynesianos que usaram principalmente o método histórico-dedutivo, mas um grande economista neoclássico como Marshall deu uma contribuição duradoura à teoria econômica desenvolvendo o modelo microeconômico; ele usou basicamente o método hipotético-dedutivo, mas nunca perdeu contato com a realidade econômica que estava estudando. Atualmente, o núcleo da teoria econômica é formado pela microeconomia clássica, pela macroeconomia keynesiana e pela teoria econômica do desenvolvimento clássico-keynesiana. A microeconomia clássica é essencialmente a teoria da alocação de recursos e a teoria da distribuição com base na teoria do valor-trabalho e não na teoria da utilidade marginal. Ela pode e deve ser complementada pelas importantes contribuições de ferramentas feitas pela microeconomia neoclássica. A macroeconomia keynesiana é aqui entendida como incluindo todas as escolas macroeconômicas que pensam historicamente. A economia do desenvolvimento trabalha com o crescimento econômico, combinando o lado da oferta do crescimento econômico, isto é, a acumulação de capital, o progresso técnico, a educação e as instituições, com o lado da demanda - novamente a acumulação de capital, as políticas macroeconômicas de curto prazo que visam ao pleno emprego, e o crescimento impulsionado pela exportação baseado em uma taxa de câmbio competitiva. Dada sua ênfase na demanda e nos preços macroeconômicos (a taxa de lucro, a taxa de salários, a taxa de câmbio e a taxa de juros), ela pode também ser chamada de macroeconomia do desenvolvimento.

O método hipotético-dedutivo é atraente para os economistas porque permite previsões precisas e, portanto, a plena matematização dos modelos. Desse modo, a economia espelha a "rainha das ciências" - a matemática. Mas, em compensação, os modelos assim desenvolvidos são incapazes de explicar os sistemas econômicos. O fracasso da teoria econômica neoclássica é particularmente claro em relação à macroeconomia. Os modelos macroeconômicos neoclássicos raramente são usados por analistas e formuladores de políticas, não apenas porque seus pressupostos são excessivamente simples, mas principalmente porque são produto de um método hipotético-dedutivo que permite a construção de modelos totalmente coerentes e abstratos com pouca relação com a realidade. Quando alguns modelos da corrente dominante, em particular modelos macroeconômicos, se tornam mais realistas, como, por exemplo, aqueles que usam a regra de Taylor, esse é um sinal certo de que estão se tornando histórico-dedutivos.

Para pensar sobre a economia, para formular as hipóteses que explicam seu funcionamento, e para propor as políticas econômicas necessárias para objetivos socialmente aceitos (estabilidade, crescimento, distribuição), o economista, cujos problemas estão hoje essencialmente ligados à macroeconomia e ao desenvolvimento econômico, deve observar a realidade, verificar como os fenômenos ocorrem e se repetem ou mostrar tendências, e a partir desse processo analítico, que é inicialmente abdutivo, mas logo se torna dedutivo e indutivo, ele inferirá seu modelo ou 
sua explicação. A objeção cética de que nenhuma inferência indutiva se justifica - o conhecido "problema da indução" de Hume -, embora interessante, não pode ser aceita - não apenas por ser contrária ao senso comum, contrária à evidência de que o conhecimento resulta em grande parte de inferências indutivas, mas também porque, como argumenta Foster (1982), a inferência indutiva se justifica sempre que representar "a melhor explicação" para o problema sob exame. Assim, o economista, nessas duas grandes áreas, adota a forma clássica da pesquisa científica nas ciências naturais: ele examina a realidade e busca regularidades. Mas faz isso de modo muito mais modesto. Ele usa principalmente a indução, mas naturalmente também a dedução. A tarefa do pesquisador é essencialmente generalizar a partir do estudo da realidade que, para as ciências sociais, é sempre uma realidade histórica. Mercado e dinheiro - os dois principais elementos dos sistemas econômicos - são eles próprios instituições e, portanto, realidades históricas.

A economia é uma disciplina em constante mudança, na medida em que os sistemas econômicos estão sempre mudando. A ferramenta de pesquisa fundamental é o método histórico-dedutivo, e uma de suas variedades - o "método do fato histórico novo". O economista começa com a observação da realidade econômica, assume que o conhecimento anteriormente acumulado é razoavelmente válido e busca fatos novos, novas regularidades e tendências que estejam emergindo historicamente. A partir dessa observação, dos fatos históricos novos observados, de sua própria experiência e das ferramentas econômicas disponíveis, ele tentará desenvolver seu próprio modelo do sistema ou complementar os modelos existentes. Ele sabe que seu modelo é intrinsecamente provisório, na medida em que a realidade sob estudo está historicamente mudando.

\section{REFERÊNCIAS}

AGARWALA, A. N. e S. P. SINGH, eds. (1958) The Economics of Underdevelopment. New York: Oxford University Press.BLAUG, Mark (2002) “Ugly currents in economics”. In Uskali Mäki, ed. (2002): 35-56.

BLINDER, Alan S. (1998) Central Banks in Theory and Practice. Cambridge, Ma.: MIT Press.

BRESSER-PEREIRA, Luiz Carlos e Gilberto TADEU LIMA (1996) “The irreducibility of macro to microeconomics: a methodological approach”. Brazilian Journal of Political Economy 16(2):15-39.

CHICK, Victoria (2004) “On open systems”. Brazilian Journal of Political Economy 24(1) January 2004: 3-16.

COLANDER David, Richard P. HOLT and J. Barkley ROSSER Jr. (2004) “The changing face of mainstream economics", Review of Political Economy, 16(4): 485-500.

DOW, Sheila C. (1996) The Methodology of Macroeconomic Thought. Cheltenham: Edward Elgar.

DOWNS, Anthony (1957) An Economic Theory of Democracy. New York: Harper \& Brothers.

ELSTER, Jon (1997) "The market and the forum: three varieties of political theory". In James Bohman and William Rehg, eds. (1997) Essays on Reason and Politics: Deliberative Democracy. Cambridge, Ma.: The MIT Press, pp. 3-33.

FERRARI, Marcos Adolfo Ribeiro (2003) "Sobre metodologia e economia: prelúdio para um corte teórico" [On economic methodology: a prelude to a theoretical approach]. Trabalho apresentado no Congresso Nacional de Economia Política. Florianópolis, 19-20 de junho de 2003.

FOSTER, John (1982) "Induction, explanation and natural necessity". In Michael Huemer, org. (2002) Epistemology: Contemporary Readings. London: Routledge. 
HABERMAS, Jürgen (1967 [1988]) On the Logic of the Social Sciences. Cambridge, Ma.: MIT Press.

GÄFGEN, G. (1963) Theorie der wirtschaftlichen Entschendung [Theory of Economic Decisions]. Tübingen. Citado por J. Habermas (1967 [1988]): 51.

HANDS, D. Wade (2001) Reflections without Rules: Economic Methodology and Contemporary Science Theory. Cambridge: Cambridge University Press.

HAUSMAN, Daniel M. (1992) The Inexact and Separate Science of Economics. Cambridge: Cambridge University Press.

HAUSMAN, Daniel M. (1994) The Philosophy of Economics: An Anthology. Cambridge: Cambridge University Press.

HEMPEL, Carl G.(1966) Philosophy of Natural Sciences. Englewood Cliffs: Prentice Hall.

HOOVER, Kevin D. (1994) "Pragmatism, pragmaticism and economic method". In Roger E. Backhouse, ed. Contemporary Issues in Economic Methodology. London: Routledge, 1994: 286-315.

KRUGMAN, Paul (1999) Development, Geography, and Economic Theory. Cambridge, Ma.: The MIT Press.

LAWSON, Tony (1997) Economics and Reality. London: Routledge.

LAWSON, Tony (2003) Reorienting Economics. London: Routledge.

MÄKI, Uskali (1992) "On the method of isolation in economics". Poznán Studies in the Philosophy of Sciences and the Humanities 26: 319-354.

MÄKI, Uskali (2002) “Some nonreasons for nonrealism about economics”. In Uskali Mäki, ed. (2002): 90106.

MÄKI, Uskali, ed. (2002) Fact and Fiction in Economics. Cambridge: Cambridge University Press.

MANKIW, N. Gregory (2006) “The macroeconomist as scientist and engineer". Journal of Economic Perspectives 20 (4): 29-46.

MILL, John Stuart. ([1836] 1974). "Da definição de economia política e do método de investigação próprio a ela”. In Bentham, Stuart Mill. São Paulo: Abril Cultural, 291-315 (Col. Os Pensadores).

MIROWSKI, Philip (1991) "The when, the how and the why of mathematical expression in the history of economic analysis". Journal of Economic Perspectives 5(1): 145-57.

MURPHY, Kevin M., Andrei SHLEIFER and Robert W. VISHNY (1989) Journal of Political Economy, 97(5) 1989: 1003-1026.

NELSON, Richard R. e Sidney G. WINTER (1982) An Evolutionary Theory of Economic Change. Cambridge, MA: Harvard University Press.

PEIRCE, Charles S. (1878) "Deduction, induction, and hypothesis." Popular Science Monthly 13: 470-482.

PEIRCE, Charles S. (1958) Charles Peirce: Selected Writings. Organized by Philip P. Wiener. Nova York: Dover Publications.

PRIGOGINE, Ilya (1997) The End of Certainty. New York: Free Press.

PRZEWORSKI, Adam (1985) Capitalism and Social Democracy. Cambridge: Cambridge University Press.

Robbins, Lionel (1932 [1946]) Essay on the Nature and Significance of Economic Science. London: Macmillan, 1946.

ROSENSTEIN-RODAN, Paul (1943) "Problems of industrialization in Eastern Europe and South-Eastern Europe”. Economic Journal 53, June 1943, 202-11. Reproduzido in Agarwala and Singh, orgs. (1958): 245-255.

SCHEFOLD, B. (1987) “Schmoller, Gustav von (1838-1917)". In The New Palgrave - A Dictionary of Economics, Volume 4. London: The Macmillan Press.

SCHUMPETER, Joseph A. (1949) “Science and ideology". In Daniel M. Hausman, ed. (1994): 224-238.

SCHUMPETER, Joseph A. (1959) History of Economic Analysis. Oxford: Oxford University Press.

SIMON, Herbert A. (1957) Models of Man. New York: Wiley.

SIMON, Herbert A. (1996) The Science of the Artificial. Cambridge, MA: The MIT Press.

WEBER, Max ([1978]1922) Economy and Society. Berkeley: University of California Press, 1978.

WEBER, Max (1906) “Objectivity and understanding in economics”. In Daniel M. Hausman, ed. (1994). Originalmente publicado em alemão em 1906.

WIENER, Philip P. (1958) “Introduction”. In Charles Peirce: Selected Writings. New York: Dover Publications: VII-XXII.

YU, Chong Ho (2005) “Abduction, deduction and induction”. Trabalho apresentado na AERA (American Educational Research Association), 2006, julho 2005. 